\title{
Marcin Choczyński*
}

(iD) https://orcid.org/0000-0002-6636-9025

\section{ACCENTUATING THE ROLE OF THE UPBRINGING SOCIETY IN KORCZAK'S PEDAGOGY}

\begin{abstract}
The aim of the article is to show the sociological elements in the education process that are present in Korczak's pedagogy, both in its scientific form as well as in his fiction aimed directly at children. Therefore, society with its educational institutions (family, school, boarding school) is recognized in this pedagogy as an important sphere of symbolic references and educational influences. The key role of society (as the most important educational institution) in shaping pupils is present in commonly known works on the sociology of upbringing (including Florian Znaniecki or Józef Chałasiński), while sociological threads in Korczak's pedagogy have not been a popular topic of separate analysis so far, apart from one monograph devoted to the subject. Therefore, this topic requires in-depth analyses and afterthought. Janusz Korczak emphasizes the role of society in a child's life, preparing them primarily for participation in social relations, through diverse forms of group life at school, whose most important achievement is the institution of student self-government. It is thus a bridge between student-oriented education and the traditional pedagogical message, involving the transmission of the requirements of specific social roles.
\end{abstract}

Keywords: Korczak's pedagogy, upbringing society, the society of adults, the society of children, directive soul, student council, kindness poll.

\section{Introduction}

The importance of Janusz Korczak's pedagogy for modern educational science is undeniable. Its influence transcends the pedagogical subject matter, and the scope of its interpretations should be also of interest to sociologists. In a similar way, we could also enquire into Florian Znaniecki's references in his views on upbringing to Janusz Korczak's ideals, which are not expressed directly, albeit they highlight the same elements, including primarily arousing creative interests, engaging pupils in adult activities (Gajda 2001: 95). Thereby, both Znaniecki's and Korczak's approaches to upbringing, have numerous common points, focusing around spiritual culture and shaping the minds of pupils.

* PhD, The Institute of Sociological Sciences, Cardinal Stefan Wyszyński University in Warsaw, ul. Wóycickiego 1/3, 01-938 Warszawa, e-mail: m.choczynski@uksw.edu.pl 
The pedagogical aspect of society is therefore emphasized in Korczak's educational works. These are the main postulates regarding the relationship between children and adults, the antagonisms within these relations and the attempts to overcome this discord. Moreover, Korczak drew attention to shaping a child's character and will in a social collectivity, including groups or categories created within an educational institution, which constitute an educational community. In this article I present a sociological reflection on the processes behind becoming full-fledged members of society, through incorporating the ideas present in Korczak's pedagogical thinking. This point of view is present in the source literature, in which the links between Korczak's pedagogy and the ideals of sociology of education are evident, as be seen in the socio-pedagogical works of Florian Znaniecki. "The search for optimization of the education process pertinent to the subject of this education is characteristic for Korczak, and for Znaniecki - for the needs of the subject that educates, on behalf of society. [...] Another common idea to both Znaniecki and Korczak is their perception of education as a relationship between an adult and a child, which should ideally be based on partnership" (Chodkowska, Bednarz-Grzybek 2014: 36).

Other education sociologists, the continuators of Znaniecki's thought and his followers, referred in their works to the fact of emphasizing the role of a community in an education process. "In an education process, as in any process of interpersonal interaction $[\ldots]$ an individual appears as a member of a social group in a certain social role. The behavior of children and adolescents in various social situations is, from the sociological point of view, a manifestation of its social role in a group or social roles in social groups. Physiologic-psychological elements of a child's age do not affect their social behavior directly, they interact as components of their social role" (Chałasiński 1969: 37). These are views referring to Korczak's idea of child activism, the self-determination of children with regard to the society of adults, its subjectivity. In the practical context, that is, in Korczak's running of orphanages and educational institutions, the involuntary shaping of the future social roles of the pupil-children taken into care is striking. This occurred due to specificity of their relations in a dense community of peers, the capability of autonomic cooperation and efficient management of such a collectivity.

The end of the $19^{\text {th }}$ century and the beginning of the $20^{\text {th }}$ century, as well as the interwar period, were marked by a boom in writing dedicated to social issues. It is worth mentioning that not only sociologists of that period depicted society in statu nascendi. Analyses regarding a specified social system can also be found in pedagogy. Visions of the proper form its should take can be found in the work of Rudolf Steiner, the founder of anthroposophy and Waldorf pedagogy (Choczyński 2013: 173-177).

Significantly, both Korczak's scholarly and spiritual formation was influenced by the contemporary Polish academics, whose ideas inadvertently filtered into his works. Among the views shaping his social mindset, to a certain extent, we can 
distinguish the works of prominent Polish sociology academics, whose body of work had, and continues to have, a great impact on the education system and education itself. The figures worth mentioning are, among others: Florian Znaniecki, Józef Chałasiński, Henryk Elzenberg and Maria Ossowska and Stanisław Ossowski (Floryńska 1997: 277). Korczak himself refers in his diary to people of culture - e.g. writers, such as Adolf Dygasiński, and scholars, such as Wacław Nałkowski, Stanisław Szczepanowski or Jan Władysław Dawid, who frequently invoked the idea of positivism (Korczak 1996: 16). Views regarding society are also externalized in Korczak's most personal work: he mentions, inter alia, the need to create institutions for young people, which, in an institutional way, would address bringing up orphans or generally difficult cases (Korczak 1996: 17-19). It should be emphasized that Korczak's pedagogical thought is defined as the "pedagogy of smart love", which incorporates kindness, empathy and reliable support towards children in an academic system of education and custodial activities (Jaw orski 1977: 10; Smolińska-Theiss, Theiss 2002: 189). Significantly, Janusz Korczak occupies a place in social consciousness through the nickname of Old Doctor, which was the name his pupils gave to him.

A certain introduction to how Korczak perceived society are provided by his views regarding both natural and human reality. In the first place, he is struck by the harmony of the natural world, its beauty, power and homeostatic equilibrium. The role of an individual is to imaginatively reshape it in the context of deeds, e.g. subjective action. On the other hand, however, Korczak's views on social reality and the essence of human beings are marked by concern and disapproval of the inequality present in the human world. He is of the opinion that the world is badly organized, and humans do not take advantage of all their potential - which results in cataclysms, including famine, poverty, war and suffering (Rusakow ska 1989: 37-38). This is reflected by his turning his attention to the community of children, as a phenomenon free of repulsive adult pattern. The subjectivity of the children's society in terms of their acquiring the cultural patterns transmitted by educational institutions is in this case a significant element brought by Korczak to the anthropocentric trend of pedagogy.

\section{The subject matter of Korczak's pedagogy}

Having faith in children's society, which is organized according to the wellestablished values and patterns, is the main thought behind Korczak's pedagogy. These views are manifested in his most widely known work - a collection of sententious notes in the volume entitled How to Love a Child. In another pedagogical manifesto, The Child's Right to Respect, the Old Doctor also makes certain observations and expresses his views regarding the social conditions of child pedagogy. Korczak's reflection is developed by the use of typically sociological terms, e.g. "social 
class", as well as disapproval of the involuntarily use of educational "patterns" in child-rearing. Korczak is also against setting out the path of a child's education and professional career in an autocratic way, which is often "the ambition of the mass" and does not consider the characteristics of the individual (Korczak 2004: 17-18). Anti-authoritarian statements regarding the child's self-determination of their future social role is clearly apparent.

Korczak viewed the ideal of a pedagogue as complete sacrifice for the cause of a child, who in turn should take a subjective position in the process of upbringing. The author believed that, by showing love and boundless commitment, it is possible to build lasting cooperation between two communities that had been antagonistic for centuries, namely adults and children, which would be realized by reciprocal understanding. "Children brought up in this atmosphere were to be the nucleus of a new society, free from hypocrisy and injustice, intolerance and coercion, devoted to free and creative work" (Matyjas 2003: 800). Korczak's inclinations for social work are revealed here, which refer directly to a certain sociological forecast, or even sociological fantasy, where the society of the future is based on understanding and cooperation of the two hitherto antagonistic groups.

Many experts in this field emphasize the overall system regarding knowledge of children that Korczak was striving to develop during the long years he spent working as a pedagogue. Through collecting detailed descriptions of children's somatic appearance, changes in their bodies, as well as observing their natural behavior in his educational institution, Korczak was trying to explore the essence of childhood, which was the goal of his life-long research (Szlązakow a 1978: 7). Gathering data and juxtaposing them with his medical practice, together with his educational talent and skillful observations of social conditions, Korczak was able to undertake multiple analyses and comparisons, which were incorporated in his literary legacy.

It is worth mentioning that on every possible occasion Korczak frequently and firmly emphasizes social aspects of children's functioning as beings and a category distinct from adults (Korczak 2004: 56-57). Nevertheless, the Old Doctor also underlines the social message, pointing out the role of giving orders and imposing bans on children in the process of bringing them up (Korczak 2004: 58-59). What is more, Korczak isolated the so-called "family spirit" in his work, indicating its key social aspect - "the educational area is called the family spirit, which rules; an individual member cannot take just any position towards it. This directive spirit has enough power to compel; it does not tolerate resistance" (Korczak 2004: 75). This approach reveals certain attempts to employ the relations dynamics in a specific social group, namely the family environment.

Korczak directed his cognitive activity at describing specific principles governing children's behavior. In his authorial educational institutions he was striving for a vision of upbringing which above all would not be limiting for a child's development, or stifle their talents and objectives - "if we divided mankind into adults and children, and our life into childhood and adulthood, we could observe that there 
is a great deal of child in this world. However, focused merely on our fight, our concerns, we fail to perceive that, just as we once failed to notice the woman, the peasant and the enslaved social stratums and nations" (Korczak 2004: 88). The propensity to strictly sociological comparisons is evident here, through highlighting the marginalization of children, and referring this state of affairs to the situation of collectivities disadvantaged in the past. The tone of Korczak's work is focused therefore on the aim of discovering the integrity of the child and understanding the idea of "the child nation of the little ones", the name used by the Old Doctor in his pedagogical works - the treatises How to Love a Child and The Child's Right to Respect (Sitko 1993: 60).

As a pediatrician, educator and writer, Korczak had an opportunity to assess his pupils from various perspectives which were complementary to each other. His writing is filled with idealism, which influences the issues of children's wellbeing, their right to happiness. "The Old Doctor [...] taught children humaneness. Together with children he dreamt of the reconstruction of the world, the annihilation of exploitation, the abolition of poverty and disease. He dreamt together with children of a democratic, law-abiding and just nation" (Marzec 2003: 66). Korczak's views, empowering children to decide on such issues within society as, for instance, power, its legitimization and self-determination, impressing on his readers his uncompromising nature, as he treated children like a peculiar collectivity, whose rights are, according to him, clearly violated.

The aim of getting to know children is also the pursuit of their proper functioning in educational institutions and schools (Korczak 2012b: 55). The Old Doctor emphasizes the role of school, the fact that it organizes a student's day and strives to explain the pedagogical intricacies, which should not focus merely on the result, but most importantly present the benefits of acquiring new information, and thereby preparing the pupil for the requirements of the environment that awaits after leaving the educational establishment (Korczak 2012b: 56-58). This was the idea behind Korczak's creative childcare education (Dauzenroth 2012: 99). This confirms the subjective approach to children, and their affirmation as people, entities as yet not fully discovered. His views refute, to a great extent, the image, or even myths, of a happy, carefree childhood. Looking after children from dysfunctional families gave Korczak an idea of how a child might be misunderstood as a person whose opinion is not taken into consideration by adults (Bińczycka 2009: 47).

The role played by the collective in the process of upbringing should be noted, which highlights the necessary influence of values established by the community. On numerous occasions, Korczak refers in his pedagogical writings to the role of society in a child's upbringing, or to the essence of socialization, which is seen as acquiring any information from the members of collectivity. He admits directly that a child is a natural participant of society, from which they acquire certain communication competences designed to build relations in their future lives as adults. "Humans possess a patrimonial and acquired character. The former is inherited from 
our parents, the latter is the result of upbringing. By upbringing we understand the external influence; parents, relatives, friends, servants - in other words this environment brings up a child; a man is brought up by life, by the world" (Korczak 1994a: 14).

Korczak, both as a pedagogue and a pediatrician, pays attention to children imitating their parents. This activity is a sort of initial socialization, as it constitutes the earliest stage of learning certain traditional social behaviors (Korczak 2004: 94-95). Therefore, this imitation serves a pragmatic role - it is, to a certain extent, forming children's inclination to meeting the requirements of a social role. We may find an analogy to the category distinguished by Józef Chałasiński, namely that of the transition from an educated soul to a real person in the process of upbringing, through the focus of educational influences in the period of puberty. The candidate for the role of an adult makes an attempt to enter into the role of an adult, a fully-fledged member of a given collectivity (Chałasiński 1969: 48). Moreover, "Korczak's fictional works clearly illustrate his idea of how the adults' reality is reflected in the child's conscience and world" (Wołoszyn 1978b: 72). It is also accepted nowadays in the field of developmental psychology that imitation plays a crucial role in the early stage of child adaptation to social reality.

It may be therefore assumed that with his conception of child imitation Korczak refers to the sociological process of socialization, which reflects the cultural message aimed at pupils - as the future members of social roles (Tillmann 2006: 124-125). The aim of socialization is also to achieve integration with a social group, through acquiring the culture of this group and placing oneself within this group (Borowicz 2002: 42). Socialization is this directional process "introducing" a pupil to society, as well as shaping their will, which in Korczak's pedagogy was the subject of multipronged formation in educational establishments.

The imitation process, as the most primary element of socialization, takes place above all in the fundamental family group. Family is also the essential point of reference, since its norms and values are internalized by a child in a natural way, as their message comes from the most important people in their life - their parents. Imitating the behavior of their mother and father (perceived as the closest people) constitutes a child's natural course of development. The identification of family norms and values is in this case the basis on which a child establishes community relations (Jundziłł 2004: 197). In his works, Korczak describes the authorities children have, and to which they appeal in certain life situations, though gradually expressing their appreciation for adults (Korczak 2004: 128).

Proper upbringing is not possible without respecting a child as a fully-fledged person. This act, especially taking into consideration autotelic and non-directive relations between children and adults, should become, according to Korczak, universal and dispel the faulty opinion that a child is the parents' property (Korczak 2004: 8-9; Bińczycka 1999: 124). Therefore, Korczak's pedagogy becomes a deeply anthropocentric theory, which takes into consideration the needs of the child and their self-determination on fundamental issues. 
The attempt to explore the nature of a child is interwoven in Korczak's pedagogy with the social enthusiasm for the reorganization of society towards a better treatment of children. Korczak notices and clearly condemns the exploitation of children and their deprivation by adults, which was widespread at that time. When describing these phenomena, Korczak applies certain labels including: "the children's society" (Korczak 2004: 145), "the enslaved class" (Korczak 1958b: 6-7), "the serf class" or, as mentioned before, "nation of little ones" (Korczak 1958b: 16). Underestimating the importance of the issues regarding children, and the lack of understanding, lead to misery in their lives; the trauma they experience may resurface throughout all their future life (Korczak 1928: 3-4; Lewin 1986: 34).

Korczak did not accept the social roles assigned to children and imposed by adults. In his pedagogical writings, e.g. The Child's Right to Respect, he asserts that adults have certain generalizing tendencies to perceive and emphasize the worst aspects of children's behavior, while tending to ignore their accomplishments and appropriate behavior. This, according to Korczak, stems from the lack of understating this specific period of development characteristic for childhood - "children constitute a large proportion of humanity, peoples nations, inhabitants, fellow citizens - constant companions. They were, they are, and they will be. Is there a life in jest? No, the childhood age - long, significant years of a man" (Korczak 1958b: 15). In response to all these inequalities experienced by children thanks to adults, Korczak expressed his famous demand - the child's right to be who they want to be (Korczak 1958b: 19-21). It constitutes the essence of Korczak's novel pedagogy, its departure from strictness and violence towards the overall learning of the specifics and circumstances of a broad scope of child behavior.

To sum up the essence of Korczak's pedagogy, it can be concluded that it is in numerous essential assumptions aligned with the sociology of upbringing, primarily emphasizing the subjectivity of a child in the pedagogical process, but assessing this upbringing from the perspective of social context. The core points of Korczak's pedagogy, which should be acknowledged within the scope of the sociology of education, are above all: the use of typically sociological terms (pattern, social class - which reveals the propensity to socialization); the antagonistic distinction between the society of children and the society of adults; knowledge development regarding the childhood period, its imitation aspects and the collective aspect; and forming proto-social institutions within training and education centers by drawing attention to the pursuit of consensus among children and caregivers. Therefore, the external axiological message should postulate the internalization of ideas or norms by children, which recognizes them as their own; as significant and valid (Mielicka 2000a: 24). Thus Korczak very frequently employs proto-sociological inclinations, draws conclusions regarding the exclusion of children from contemporary society, and describes them not only from the individual perspective, but also from the collective one, as a certain supra-individual being, which could constitute a separate subject of analyses. 


\section{Children's society versus adults' society}

In his educational works, Janusz Korczak outlined a coherent system of views regarding the essence of education and the special place of children in society. Above all, he distinguishes two collective surfaces - the society of children and the society of adults. These two dissimilar elements interact constantly with one another, and this interaction is the basis of any social institution's functioning.

Even though Korczak emphasized the role of the family in the appropriate upbringing of a child, his educational activity was focused mainly on orphans, abandoned children and the ones from underclass backgrounds. It is worth mentioning that even the socializing ideas of Korczak's pedagogy did not avert the exclusion of particularly difficult individuals from the home community. Korczak pointed out that children, as a separate community, yet similar to that of the adult world, can also include psychopathic individuals within their ranks, whose stay in an educational establishment would endanger others (Mortkowicz-Olczakowa 1949: 126-127).

Korczak coordinated the creation of two extrafamilial educational institutions. One of them was The House of Orphans - an establishment set up by Korczak and Stefania Wilczyńska in 1912. It was intended for Jewish children from impoverished and dysfunctional families, including the ones deprived of any parental care. Another establishment was Our House, an educational care center of explicitly socialist genesis, established a year after Poland regained its independence (1919), set up by Korczak and the people whose views were similar to his, including Maryna (Maria) Falska. Our House took in Polish children from poor families, the descendants of political prisoners, and orphans. Significantly, Korczak always stressed the importance of segregating Polish children from the Jewish ones, due to the cultural and religious differences (Olczak-Ronikier 2011: 291-298).

An educational institution is therefore a place where the social relations of a child are intensified. Contacts with new individuals are crystallized there, contacts which would never be made in their family environment or close neighborhood. School friendships are often more solid than the ones made before, due to the fact that the basis of this friendship is not only the play group, but also the group aim - connected to e.g. group learning. School also introduces a certain order into a child's day, instituting obligatory activities in a friendly environment adjusted to their needs (Korczak 2012b: 55). School friendships often continue in adult life, which reflects, on the one hand, the enduring nature of this type of socialization. On the other hand, however, Korczak emphasizes the role of the closest family, emotional ties and obstacles which may occur when changing the place of living - far from the immediate family, in a new environment of a boarding school or dormitory - "a child experiencing a painful detachment from a family, having no strong bonds with the children's society, feels greater sorrow as there is nobody to help them, nobody to turn for advice, nobody to hug" (Korczak 2004: 145). 
Authors researching Korczak's ideal of upbringing point out the division of the social world into the areas belonging to adults and children. The reciprocal alienation of these two worlds is on many occasions emphasized by Korczak, and it constitutes a counterpoint to the presented explanation. "A child's world reflects - according to Korczak - everything that takes place in the dirty world of adults. Children, while imitating life, conversations, struggle of the community they grew up in, provide society with representatives of all sort of people and manifestation of all unworthy deeds" (Jasiński 1999: 114). It might be said that the child's world is a reflection of the real adult existence, because it is the pattern a child subconsciously follows. The aim of Korczak's pedagogy was to demonstrate to his contemporaries the concept of "the real children's society", which in a certain way imitates institutions known from the adult world. A novel view on how children self-govern stems as well from the importance of underlining their capability for social organization (Korczak 1948a: 158). This form of self-determination enables subjectivity in the decisionmaking process, as well as a certain amount of independence from a traditional pedagogue, as every aspect of a group's functioning (including punitive measures towards the deviants) is coordinated within the area of self-rule. What is more, also adults, including the establishment's personnel, are subject to the constituted government. Thanks to self-determination, children taught each other their own rights and duties, learnt in practice the mechanisms governing a collectivity, and acquired altruistic competences towards another person (Wołoszyn 1978a: 7-8).

On some occasions, Korczak made negative references with regard to tradition, seen as a significant element that blocks the free development of individuals, as it tries to fit them into the provided framework, not allowing unconstrained expression and serving as a tool of oppression. On the other hand, however, "all of this, dictates [...] life regulations for the time being, only for today" (Korczak 2012b: 129). The Old Doctor himself accentuated the role of the past, similarly to Znaniecki. "Janusz Korczak and Florian Znaniecki shared also the idea of social progress and the vision of achieving this progress through forming outstanding personalities" (Chodkowska, Bednarz-Grzybek 2014: 99). The society of children is therefore artificially limited by adults, due to the belief in their fragility, lack of rightful privileges, as in the case of adults (Rusakowska 1989: 38). Korczak himself in his writings repeatedly deplored that the society of children and the society of adults were so antagonistic and struggle to peacefully coexist, that they cannot unite and constitute a united entity. "It is either an adult life on the sideline of a child's life, or a child's life on the sideline of an adult's life. When will this particular moment of honesty come, when the lives of adults and children become equivalent?" (Korczak 1958a: 42).

Frequently in the pages of a publication dedicated to the issue of upbringing in the spirit of Korczak's pedagogy, one can encounter a statement regarding a certain social agreement that exists between the adults' and children's worlds. This agreement is based on the understanding and commitment of both children 
and adults (Korczak 1994b: 15-16). It specifies the reciprocal rights and duties of both parties towards each other (Lubojem ska 2012: 85). Significantly, Korczak, even though he is perceived nowadays as a follower of anthropocentric pedagogy, never had any dealings with the extreme stance in this perspective, namely that of the child-centered educational approach (pedocracy). He condemns excessive child privileges and emphasizes the importance of the obligations they should honor in their relations with adults. Therefore, his pedagogy is a balance between child's rights and obligations towards the family and society. This point of view corresponds to other postulates put forward by Korczak, who perceives the child as an object of research, not the object of a cult, as is often observed in the perspective of the orthodox child-centered educational approach (Lewin 1999: 208-219).

In discussions regarding Korczak's views on the vision of society, one can distinguish voices arguing for a certain social agreement concluded between individuals, which can be found in the works of the Old Doctor. The pivotal position in his works is taken by the individual who is able to influence group behavior (Korczak 1948a: 137). This collective is therefore, according to this assumption, a form of consensus made between particular persons. Creative transformations are also the domain of individuals (Dębnicki 1985: 134). Korczak's pedagogy and its social implications can be placed within the claims of nominalist meta-sociology, where the cultural studies stances stem from (which are close to Florian Znaniecki), or generally - all interactive sociology which emphasizes interpretative attitudes.

Korczak's educational activity reveals that the ideals held by an individual should interweave in harmony with the functioning of a social group. This is why every child in Korczak's establishment was continually directed to a peer group, and it was in this environment that child development was to have taken place. Korczak also held the view that the individual should themselves take advantage of the abundant opportunities offered by versatile interactions with a collectivity, as they the develop internal features of a person, including self-awareness, or applying positive self-evaluation (Korczak 2004: 162; Jakubowski 1996: 84-85). The influence of social relations on any other individual characteristics brings Korczak's concept close to the classic representatives of sociology, e.g. Émile Durkheim.

Nevertheless, some critical modern pedagogists and educational theorists emphasize that the ideal of a dyadic society of adults and children is confrontational at its core. The antagonistic presentation of two parts of society exposes Korczak's work to a more acute objection - that children are not adjusted to general society, and that the environment that was supposed to be created in the establishments run by Korczak himself was artificial (Gurycka 2002: 129). On the other hand, Korczak's school model is often quoted as a model of responsible pedagogy and acclaimed for teaching the habits of collaboration and cooperation.

In Korczak's pedagogy we can find certain statements claiming that adults take advantage of their minor charges, perceiving them as defective, not predestined to fulfil their social roles. "Society refuses to acknowledge [...] children - according to 
Korczak - human rights, seeing in a child merely a candidate for a human, a child is yet to become one day, in the future. Therefore, adults tend to ignore children, or are even hold them in contempt" (Tarnowski 1990: 59). The humanistic perception of childhood in Korczak's pedagogy surpasses and looks beyond the strictly determinist view on molding pupils in the process of upbringing and defining their future social roles. Yet on the other hand, Korczak himself points out the complicated role of parents in the process of shaping these future roles. This stage, which could be used by parents in order to prepare themselves and their child for the new tasks awaiting them, is a period of peace and rest, without any concerns (Korczak 2004: 147-148).

Korczak's views outlined above regarding the role of a community in the process of upbringing therefore align with the findings made by the classic representatives of developmental sociology, including Florian Znaniecki, whose widely recognized monograph portrays the upbringing society as a major institution of socialization (Znaniecki 2001b: 13). The very process of culture transmission aimed at children takes place in smaller communities, e.g. a family, neighborhood or a peer group. The fact that the role of the upbringing society is emphasized by Korczak's pedagogy allows us to classify it as a typically social conception of the cultural transmission of superpatterns (Chodkowska, Bednarz-Grzybek 2014: 152).

What is more, Florian Znaniecki draws our attention to the importance of a pupil's activism in the relational aspect of a social group, where they can, in a creative way, organize their social personality, therefore it could be stated that such a pupil: "molds himself as a social entity" (Znaniecki 2001a: 92). One of the most significant points of reference is the social circle children have direct contact with (Znaniecki 2001a: 95), which again could serve as an analogy to Korczak's educational model in social care institutions for children. Accordingly, both in Korczak's pedagogy and in the sociology of education, there are evident tendencies that bring together the society of adults and children, rather than separate them. This can be achieved by reciprocal understanding, and by acknowledging the complementarity of these two forms. Children and adults play reciprocal functional roles for each other, based on exchanging experiences, forming the social role or even giving support, and the feeling of generational and cultural transmission.

\section{The children's society in Janusz Korczak's fiction and social journalism}

The legacy of fiction writing left by Korczak serves as an example of how children's society functions in a mainly adverse adult environment. Young people are depicted here as positive characters, who actively strive for a shift in the existing reality. In this way, Korczak's social views are presented in an allegorical way. A way that imprints itself in the memory due to the attractive form it takes, as 
a background of a dynamic plot, obviously focused on child characters. It is worth noting that the descriptions of literary forms mentioned below are only a certain supplement, an enrichment of the content presented by Korczak in his pedagogical writings aimed at adult readers, in other words the aforementioned The Child's Right to Respect and How to Love a Child.

According to Korczak's pedagogy, a child is primarily a subjective entity, independent; an individual who never belongs to anybody else, even to their own mother. However, family life is most appropriate for a child, which presupposes a community. Placing a child in a family reality constitutes for them a safe anchor and a natural environment for building social contacts, which are extended with time, although the basic socialization takes place in a family (Korczak 2004: 8-11). A belief in a child's subjectivity and their sovereignty are the main motifs in Korczak's fiction.

Korczak's most famous and widely-read publication was King Matt the First. It is a story about a little boy, a king's son, who unexpectedly ascends to the throne due to his father's death. The story's most innovative and cutting-edge perspective is the idea that a child may be able to hold the highest social status in a given state, namely the position of the king. One can observe a complete reversal of the well-known social order - the decision-making power is taken by the minors, in the person of Matt the First, pushing adults to the background. It is also an allegorical representation of Korczak's pedagogical views, who called for putting the spotlight on children's issues. The representative of the children's society takes power and attempts not only to govern his peers, but also the adults. Korczak tries to exhibit the difficult art of compromise and the requirements encountered by a person in such a noble position - again we can find here a reference to the ideal of self-government worked out in his establishment, as well as a depiction of governing a community (Korczak 2005: 10-13). The society ruled by a minor king seems utopian, however Korczak strived to present the child as an equal of an adult, a boy capable of fulfilling his social roles, including the most desirable ones.

King Matt on the Deserted Island is a continuation of the story featuring the child king. Here, Korczak addresses the issue of false accusations made against children by adults (Korczak 2001: 5-8). The exile is portrayed primarily as the re-enfranchisement of the King of Children. Both of the stories about Matt the First may be treated as allegorical pedagogical treatises, which diagnose the social issues of the time in a very insightful way, and at the same time present Korczak's postulates regarding equality of children's rights with the rights of adults.

Another fictional publication which raises the issue of child participation in the forms of life traditionally reserved for adults is a novel entitled Bankruptcy of Little Jack. It tells the story of a child co-operative established by the titular protagonist. This is a strictly positivistic story, emphasizing such social values as work at the grass roots level, altruism, economization of activities, responsibility or selfless help, and the rationality of child activities. With this story Korczak seems to ask 
the question: "why do children, despite having certain responsibilities, not have the same economic rights as adults?" (Korczak 2012a: 220-221).

It can be asserted that the counterpoint of this publication is another novel by Korczak - Child of the Drawing Room. In the pages of this novel Korczak presents the story of a bourgeois family whose head is an affluent and influential industrialist. It is a so-called bourgeoisie satire, which seeks to depict the hypocrisy and a distorted idea of money manifested in the behavior of adults. A minor character has to live up to his parents' expectations, which are excessively high due to their social status. This improper rearing leads to family disintegration and the tragedy of a child who is not able to fulfil the structural demands of the prestigious social role to which, due to the fact of having been born in this particular family, he is predestined (Korczak 1980: 16-19).

It should be noted that Korczak's fiction comprises not only positivist or rationalization elements - one can also encounter certain fairy-tale moments, which refer to the irrational order. This is the image portrayed in Kaytek the Wizard. Through the plot Korczak strives to impress on the reader the fact that the society of adults, by rejecting the fairy-tale elements in their lives, have lost, contrary to children - a certain willingness to alter the reality around them, the process of shaping it. It also suggests a retreat from the idealistic and thus creative way of thinking (Korczak 1997: 36-39).

Korczak warns his readers against academic discussions regarding children which do not contribute anything to the real improvement of their situation. In a humorous publication entitled Fiddle-Faddle, the author presents a number of scenes concerning adults' reflections on the future of children and mocks the old tired mantra, repeatedly affirmed by adults that "children are the future of the nation" (Korczak 1905: 45-47). The society of children is therefore treated with false attention and raising the issue in adult conversations is simply a courtesy.

The novel Children of the Streets is meant to raise awareness of poverty among children and it constitutes a manifesto for improving their fate. In this work, Korczak employed his perceptions from the streets of Warsaw, where he witnessed children attempting to make a living when their financial situation was disastrous (Korczak 1901: 4-8).

What is more, Korczak published short columns in the pages of the contemporary newspapers, in which he voiced his opinions on numerous issues, including his thoughts regarding strictly social problems. Korczak's journalistic works are filled with socialistic enthusiasm for reform; here he expresses his personal opinion on the surrounding reality, and most frequently takes a critical tone, especially when it comes to the position of children in this system. At the same time, Korczak asserts that children, despite the merits of their mind and perception, are not allowed to take part in the equal exchange of their views with adults (Korczak 1994c: 149).

In his journalism, a postulate of great importance seems to be the call for child's happiness, identified by Korczak as proper upbringing, realized by conscious adults 
who assume full responsibility. Moreover, he proposes that children should be acknowledged as human beings, with all the rights they are entitled to. In reference to this statement, Korczak also recommends replacing the present strict upbringing based on fear with that based on love, respect and trust (Korczak 1998: 151).

\section{The children's self-government as an element of educational society}

It is worth noticing that in his works Korczak made references to the most glorious examples of the Polish pedagogical thought and reiterated views that had already been expressed by the Commission of National Education, which was established in 1773. One of the achievements of the Polish pedagogical thought, consistently implemented by Korczak in his educational institutions, was the idea of pupils' self-government. The most significant merit of this institution is undoubtedly the possibility of children's self-actualization and self-organization, since it is they who decide about the hierarchy or sanctions in their peer group (Korczak 1948a: 155; Kamiński 1962: 35-40). In a number of his works, Korczak advocates establishing specialist institutions targeted solely at children, including hospitals, workshops or organized holiday retreats, like summer camps (Korczak 1948c: 91-92; Falkowska 1979: 58). The Children's Self-Government, as an authority shaping the habit of cooperation and accountability for oneself and for others, is meant to counteract the view on the role of children that is destructive in the longterm; their statutory subjectivity in a society. It also promotes the ideal of children's social participation, as a category that is essential and important for the institutional order of modern, complex societies (Michalak 2010: 233). This is manifested, for example, in the institution of a government council which is introduced in Our House (Rogowska-Falska 1928: 48-49).

Korczak advocated to a great extent the participatory character of the child's stay in an educational institution, introduced the model of engaging his pupils in the life of an establishment and, consequently, created a community with a vision which allied both pupils and teachers. The Old Doctor emphasized on numerous occasions that he did not accept the state of the society that was contemporary to him, hence the importance of the Children's Self-Government, as the finest form of cooperation, was very much emphasized by him, as it constituted the basis for building the future society, which would not be so dichotomous and would not exploit children due to a belief in their defectiveness (Korczak 1948b: 17-18; Wróblewska 2003: 51).

The key principle implemented in Korczak's establishments was the rule of law. This is what made the pedagogical course of this establishment so successful. "The Orphan House was described by Korczak as lawful society in miniature. [...] He promoted there a reciprocal kindness, the importance of forgiveness, 
tolerance. Kindness and true dialogue could naturally flourish there. The naturalness of the features mentioned above derived from the fact that Korczak was their embodiment, not only the transmitter and intermediary between the external world of values and a child" (Bińczycka 2006: 33). It is worth pointing out that this government in Korczak's establishments was a complex institution, comprising a few statutory bodies - it was therefore not a homogenous organ. In order to ensure legitimate functioning, a decision regarding its division was made. The authority was thus divided between the Government Council, the Peer Tribunal and the Parliament (Rogowska-Falska 1928: 31-67; Olszew ski 1993: 54). The self-government model employed by Korczak in his establishments was created in accordance with real democracy.

Introducing the institution of a court, whose verdicts were delivered by children themselves, appealed to the child's sense of justice. The decisions given by children constituted the highest authority that defined a child's place in the establishment's society (Korczak 1948a: 158; Urbańska 1979: 83). Other people's beliefs regarding a given person constitute a point of reference for them, and a certain social reflection which depicts the individual's perception by the group. These forms of reciprocal control reinforced a child's willingness to improve, due to the fact that the main stabilizer of behavior was peers, not the older generation of caregivers (Pyrzyk 2003: 60-61).

The children's society could be characterized as having a certain stratification, and it was based not on the assets they possessed, as in the case of adults, but on the functions its members performed within this society. "It is commonly known that the children's society in Korczak's establishments had a class system. A poll determined a child's position in this society, which it was possible to correct later on. $[\ldots]$ Certain rights were attached to those positions [...]. Everyday life was subject to appropriate rigor, according to a strict order of duties, a hierarchy of positions, teachers, etc." (Mortkowicz-Olczakowa 1949: 125-126). The kindness poll mentioned above, apart from having typically stratificational functions, also played also functioned as a certain educational method. It pointed out to the pupils faults in their behavior and diagnosed how they were perceived by their group. Some authors who research Korczak's pedagogy claim that this sort of poll may serve the role of a real sociometric technique, demonstrating the intensity and arrangement of relations within a certain social group (Regulska 1979: 112). This view on the poll brings it even closer to the social aspects of pedagogy emphasized so much in Korczak's approach.

It could be therefore concluded that the idea of children's self-government in Korczak's pedagogy makes certain references to their socialization and social adjustment. "The essence of practical, directly visible importance of the children's government is simple tasks: it is about the most effective regulation of collaboration between individual children, as well as these individuals and the group, and 
establishing real cooperation with their teachers" (Jaw orski 1977: 64). Thus, the children's society in Korczak's pedagogy has a chance for collective practices of negotiating the meanings, regulations and interpretations of their own behaviors, thereby implementing "adult" social institutions.

\section{Conclusion}

Korczak's pedagogy made multiple references to social issues, therefore it could be said that it is directly anchored in the community aims, coordinating the structure of a certain collectivity. Korczak put a great deal of effort into creating an education system that could bring tangible benefits to society, stressed the necessity of fixing society through upbringing based on grassroot initiatives and democratic self-government, as a manifestation of the self-determination of an individual. "The Old Doctor's achievements in favor of education and education and care, belonged to a worldwide current called the new education. It was a humanistic concept, focused on extracting and developing in educational work the innate talents and abilities of a child, equipping the child with power that would enable them to reshape the world" (Smolińska-Theiss, Theiss 2002: 189).

The vision of humanistic pedagogy proposed by Korczak is not directed against a group. On the contrary, it strives to enhance it and interact with it through shared values. Korczak's public-spirited views entail that his works can be interpreted as proclaiming a vision of society as a consensus of the categories which until that moment had been antagonistic - adults and children, with the clear elevation of the latter group, which had thus far been neglected. The author frequently underlined the importance of collectivity in the common pursuit of humanity, therefore it can be stated that both in his writing and, to a great extent, in his pedagogical activity, he applied the ideas of the upbringing society. Thus, it can be concluded that the idea of Korczak's compliant pedagogy is closely associated with conditions of the sociology of education, emphasizing above all the tendencies to the proper fulfilment of roles within social groups (Jaworski 1977: 10; Mielicka 2000b: 44-45). The sociology of education, in its classical form, indicates that social educational interactions should also involve - apart the obvious fact of shaping a potential member into a full member of a given society, and the personal development of an individual - expanding their awareness and providing an opportunity to satisfy aspirations (Leszniewski, Wasielewski 2013: 21).

It is thanks to the upbringing society and the relations within this society that a child is able to develop to the greatest extent. Therefore, in the establishments set up by Korczak this society in miniature was cultivated, as it showed pupils how to truly fulfil their goals, according to the collective character of the whole community. In one of his works - Momenty Wychowawcze [Educational Moments - translator's note] - the Old Doctor confirms the prosocial character of his pedagogy, 
proclaiming: "you do not work for the motherland, society, future if you do not work towards enriching your own soul. Only by receiving, can one give; only by increasing one's spirit, might this growth be enhanced" (Korczak 1924: 5). What is more, in his works Korczak outlines the importance of the proper transmission of knowledge, adjusted to their cognitive needs, yet usable in the future acquiring of socialization content. "A child is a foreigner who does not understand a language, directions, principles and customs. Sometimes, he prefers to have a look around without any help; and when lost - asks for a clue and advice. Therefore, a guide is required to answer the question with kindness" (Korczak 1958b: 17). This citation can serve as a summary of Korczak's idea - he demands respect for child nescience; however, he emphasizes the empathic, conscious role of a community (society, social group, institution) as a point of reference, being able to become the "guide" and impart the social message.

On the other hand, in Florian Znaniecki's pedagogical works the term "subjectivity of a charge" can be found, which describes a person inclined to reshape social structures around them in a creative manner. Therefore, they are active agents, acting in the field of relations and ready to be empowered (Jankowska 1996: 117). Consequently, in both of the systems common to these two great scholars, synchronous areas can be distinguished.

Emphasizing the role of society in Korczak's pedagogy will therefore lean primarily on distinguishing such elements of social bonds as: the sense of autotelism and the sense of ownership in the relation between a pupil and a teacher, self-government, empowering children's communities with the right to issue binding decisions, the "self-managing" children's community. Children's self-government, which is expressed in representative institutions, including the peer court, became the principal inclination of the prosocial idea in the whole of Korczak's pedagogy, introducing to its pupils the importance of understanding and cooperating within a social group. Introducing pupils to the decision-making process, giving them an opportunity to express their opinion, allowing them to take a stand on significant issues and vesting them with numerous rights as well as obligations associated with certain requirements of social roles. Korczak's pedagogy constitutes, therefore, especially contemporarily, a return to a certain social agreement, a consensus between children, adults, pupils and teachers, which is so rare in atomized modern educational systems, which are focused more on the competitive aspect of co-existence.

\section{Bibliography}

Bińczycka J. (1999), Korczakowskie spojrzenie na rodzinę, [in:] J. Bińczycka (ed.), Korczakowskie dialogi, Wydawnictwo Akademickie Żak, Warszawa, pp. 116-125.

Bińczycka J. (2006), Janusz Korczak - realista czy utopista?, [in:] I.J. Pyrzyk (ed.), Pedagogika Janusza Korczaka - realizm czy utopia?, Oficyna Wydawnicza LEGA, Włocławek, pp. 29-34. 
Bińczycka J. (2009), Spotkania z Korczakiem, Wydawnictwo Olsztyńskiej Szkoły Wyższej im. Józefa Rusieckiego, Olsztyn.

Borowicz R. (2002), Socjalizacja, [in:] W. Kwaśniewicz (ed.), Encyklopedia socjologii, vol. 4 (S-Ż), Oficyna Naukowa, Warszawa, pp. 42-46.

Ch ała s ińs ki J. (1969), Społeczeństwo i wychowanie, Państwowe Wydawnictwo Naukowe, Warszawa.

Ch oc zy ń s k i M. (2013), Elementy spotecznego charakteru wychowania w pedagogice waldorfskiej, "Seminare. Poszukiwania naukowe", vol. 33, pp. 165-178.

Chodkowska M., Bednarz-Grzybek R. (2014), Twórczość i praktyka pedagogiczna Janusza Korczaka w kontekście teorii socjologicznej Floriana Znanieckiego, Wydawnictwo Uniwersytetu Marii Curie-Skłodowskiej, Lublin.

Dauzenroth E. (2012), Janusz Korczak. Życie dla dzieci, transl. T. Semczuk, Wydawnictwo WAM, Kraków.

Dębnicki K. (1985), Korczak z bliska, Ludowa Spółdzielnia Wydawnicza, Warszawa.

Falkowska M. (1979), Dziecko w pogladach pedagogiczno-społecznych Janusza Korczaka, [in:] P. Poręba (ed.), Wartości pedagogiki Janusza Korczaka, Towarzystwo Naukowe Katolickiego Uniwersytetu Lubelskiego, Lublin, pp. 51-63.

Floryńska H. (1997), Pedagogika jako filozofia stosowana, [in:] H. Kirchner (ed.), Janusz Korczak. Pisarz - wychowawca-myśliciel, Instytut Badań Literackich, Warszawa, pp. 249-278.

Gajda J. (2001), Koncepcje Floriana Znanieckiego - zbieżne z założeniami pedagogiki kultury (głos w dyskusji), [in:] H. Rotkiewicz (ed.), Florian Znaniecki. Myśl społeczna a wychowanie. Inspiracje dla wspótczesności, Wydawnictwo Akademickie Żak, Warszawa, pp. 91-96.

Gurycka A. (2002), Korczakowskie inspiracje..., Wydawnictwo Naukowe Scholar, Warszawa.

Jakubowski M. (1996), Janusz Korczak i jego dokonania, Wydawnictwo Wyższej Szkoły Pedagogicznej, Częstochowa.

Jankowska D. (1996), Koncepcja wychowania Floriana Znanieckiego i jej znaczenie dla wspótczesnej pedagogiki, Wydawnictwo Wyższej Szkoły Pedagogiki Specjalnej im. Marii Grzegorzewskiej, Warszawa.

Jasiński Z. (1999), Zaufanie w pedagogice Janusza Korczaka, [in:] J. Bińczycka (ed.), Korczakowskie dialogi, Wydawnictwo Akademickie Żak, Warszawa, pp. 102-115.

Jaworski M. (1977), Janusz Korczak, Wydawnictwo Interpress, Warszawa.

Jundziłł E. (2004), Opieka nad dzieckiem w rodzinie w świetle pogladów Janusza Korczaka, [in:] J. Żebrowski (ed.), Społeczeństwo. Opieka. Wychowanie: prace dedykowane Irenie Jundziłt w osiemdziesięciolecie urodzin, Wydawnictwo Uniwersytetu Gdańskiego, Gdańsk, pp. 187-198.

Kamiński A. (1962), Korzenie historyczne samorzadu dziecięcego Janusza Korczaka, [in:] I. Newerly, A. Kamiński, W. Żelazko, Samorząd uczniowski w systemie wychowawczym Korczaka, Nasza Księgarnia, Warszawa, pp. 33-50.

Korczak J. (1901), Dzieci ulicy, nakład A. Pajewskiego, Warszawa.

Korczak J. (1905), Dzieci to..., [in:] J. Korczak, Koszałki Opałki (Satyry społeczne), Księgarnia Powszechna, Warszawa, pp. 43-48.

Korczak J. (1924), Momenty wychowawcze, Nasza Księgarnia, Warszawa-Lódź.

Korczak J. (1928), Wstęp, [in:] M. Rogowska-Falska, Zakład wychowawczy "Nasz Dom”. Szkic informacyjny, Towarzystwo "Nasz Dom", Warszawa, pp. 3-5.

Korczak J. (1948a), Dom sierot, [in:] J. Korczak, Jak kochać dziecko. Internat, kolonie letnie, dom sierot, Spółdzielnia Wydawnicza "Książka”, Warszawa-Kraków, pp. 133-209.

Korczak J. (1948b), Internat, [in:] J. Korczak, Jak kochać dziecko. Internat, kolonie letnie, dom sierot, Spółdzielnia Wydawnicza "Książka”, Warszawa-Kraków, pp. 9-86.

Korczak J. (1948c), Kolonie letnie, [in:] J. Korczak, Jak kochać dziecko. Internat, kolonie letnie, dom sierot, Spółdzielnia Wydawnicza “Książka”, Warszawa-Kraków, pp. 87-131. 
Korczak J. (1958a), Pedagogika żartobliwa, Państwowe Zakłady Wydawnictw Szkolnych, Warszawa.

Korczak J. (1958b), Prawo dziecka do szacunku, Państwowe Zakłady Wydawnictw Szkolnych, Warszawa.

Korczak J. (1980), Dziecko salonu, Wydawnictwo Literackie, Kraków.

Korczak J. (1994a), Dzieci, [in:] J. Korczak, Dzieła, vol. 3, Na mównicy. Publicystyka społeczna (1898-1912), part 1, Oficyna Wydawnicza Latona, Warszawa, pp. 13-15.

Korczak J. (1994b), Miłość, szacunek, zaufanie, [in:] J. Korczak, Dzieła, vol. 3, Na mównicy. Publicystyka społeczna (1898-1912), part 1, Oficyna Wydawnicza Latona, Warszawa, pp. 15-17.

Korczak J. (1994c), Szczęście dzieci, [in:] J. Korczak, Dzieła, vol. 3, Na mównicy. Publicystyka społeczna (1898-1912), part 2, Oficyna Wydawnicza Latona, Warszawa, pp. 147-150.

Korczak J. (1996), Pamiętnik, Wydawnictwo Siedmioróg, Wrocław.

Korczak J. (1997), Kajtuś czarodziej, Wydawnictwo Siedmioróg, Wrocław.

Korczak J. (1998), Dzieci i wychowanie, [in:] J. Korczak, Dzieła, vol. 4, Szkoła życia. Obrazki szpitalne. Artykuły pedagogiczne i medyczne (1900-1912), Oficyna Wydawnicza Latona, Warszawa, pp. $147-180$.

Korczak J. (2001), Król Maciuś na bezludnej wyspie, Wydawnictwo Zielona Sowa, Kraków.

Korczak J. (2004), Jak kochać dziecko, Wydawnictwo Jacek Santorski \& Co, Warszawa.

Korczak J. (2005), Król Maciuś Pierwszy, Wydawnictwo Zielona Sowa, Kraków.

Korczak J. (2012a), Bankructwo matego Dżeka, Wydawnictwo W.A.B., Warszawa.

Korczak J. (2012b), Prawidła życia. Pedagogika dla młodzieży i dorostych, Międzynarodowa Kapituła Orderu Uśmiechu, Agencja Edytorska EZOP, Warszawa.

Leszniewski T., Wasielewski K. (2013), Socjologia wychowania w Polsce-pytania o wymiar tożsamościowy subdyscypliny, "Studia Socjologiczne”, no. 2 (209), pp. 9-29.

Lewin A. (1986), Tryptyk pedagogiczny. Korczak - Makarenko - Freinet, Wydawnictwo Nasza Księgarnia, Warszawa.

Lewin A. (1999), Korczak znany i nieznany, Agencja Edytorska EZOP, Wyższa Szkoła Pedagogiczna Związku Nauczycielstwa Polskiego, Warszawa.

Lubojemska B. (2012), Janusz Korczak - jeden z najwybitniejszych przedstawicieli wychowania w placówkach socjalizacyjnych, "Kwartalnik Edukacyjny”, no. 4, pp. 80-92.

Marzec D.K. (2003), Humanistyczne aspekty pedagogiki Janusza Korczaka, [in:] I.J. Pyrzyk (ed.), Korczak-człowiek, badacz, pedagog i wychowawca, Oficyna Wydawnicza LEGA, Włocławek, pp. 63-68.

Matyjas B. (2003), Koncepcja wychowawcza Janusza Korczaka, [in:] T. Pilch (ed.), Encyklopedia pedagogiczna XXI wieku, vol. 2, Wydawnictwo Akademickie Żak, Warszawa, pp. 799-805.

Michalak M. (2010), Korczakowskie prawo do społecznej partycypacji dzieci: gazeta, samorzad, sąd koleżeński, dziecięce zapytania i prośby skierowane do urzędów i instytucji, "Szkice Humanistyczne", vol. 10, no. 2/3, pp. 231-235.

Mielicka H. (2000a), Proces internalizacji, [in:] H. Mielicka (ed.), Socjologia wychowania. Wybór tekstów, Wydawnictwo Stachurski, Kielce, pp. 22-27.

Mielicka H. (2000b), Socjalizacja a indywidualność jednostki, [in:] H. Mielicka (ed.), Socjologia wychowania. Wybór tekstów, Wydawnictwo Stachurski, Kielce, pp. 44-48.

Mortkowicz-Olczakowa H. (1949), Janusz Korczak, Wydawnictwo J. Mortkowicz, Kraków.

Olczak-Ronikier J. (2011), Korczak. Próba biografii, Wydawnictwo W.A.B., Warszawa.

Olszewski L. (1993), Janusz Korczak wybitny polski pedagog - nowator i społecznik, [in:] T. Wróblewska (ed.), Aktualność idei Janusza Korczaka, Wydawnictwo Horyzont, Piotrków Trybunalski, pp. 50-58.

Pyrzyk I.J. (2003), Analiza krytyczna niektórych elementów działalności opiekuńczo-wychowawczej Janusza Korczaka, [in:] I.J. Pyrzyk (ed.), Korczak-człowiek, badacz, pedagog i wychowawca, Oficyna Wydawnicza LEGA, Włocławek, pp. 55-62. 
Regulska G. (1979), Korczakowski plebiscyt życzliwości a współczesne techniki socjometryczne, [in:] J. Bińczycka, K. Gorzelok (eds.), O pedagogikę jako naukę o człowieku. W setna rocznice urodzin Janusza Korczaka, Wydawnictwo Uniwersytetu Śląskiego, Katowice, pp. 109-114.

Rogowska-Falska M. (1928), Zakład wychowawczy "Nasz Dom”. Szkic informacyjny, Towarzystwo "Nasz Dom", Warszawa.

Rusakowska D. (1989), Janusz Korczak a szkoła. Poglady - oceny - doświadczenia, Instytut Badań Pedagogicznych, Zakład Systemów Wychowawczych, Warszawa.

Sitko I. (1993), Podstawowe wartości systemu wychowawczego Janusza Korczaka, [in:] T. Wróblewska (ed.), Aktualność idei Janusza Korczaka, Wydawnictwo Horyzont, Piotrków Trybunalski, pp. 59-66.

Smolińska-Theiss B., Theiss W. (2002), Widzieć w dziecku człowieka. Posłowie, [in:] J. Korczak, Jak kochać dziecko? Prawo dziecka do szacunku, Wydawnictwo Akademickie Żak, Warszawa, pp. 186-200.

Szlązakowa A. (1978), Janusz Korczak, Wydawnictwa Szkolne i Pedagogiczne, Warszawa.

Tarnowski J. (1990), Janusz Korczak dzisiaj, Wydawnictwo Akademii Teologii Katolickiej, Warszawa.

Tillmann K.-J. (2006), Teorie socjalizacji. Społeczność, instytucja, upodmiotowienie, transl. G. Bluszcz, B. Miracki, Wydawnictwo Naukowe PWN, Warszawa.

Urbańska M. (1979), Sposoby rozwijania samokontroli i samooceny w systemie wychowawczym "Starego Doktora", [in:] A. Tchorzewski (ed.), Życie i twórczość Janusza Korczaka jako temat filozoficzno-pedagogicznej refleksji, Wydawnictwo Uczelniane Wyższej Szkoły Pedagogicznej, Bydgoszcz, pp. 80-90.

Wołoszyn S. (1978a), Janusz Korczak: rodowód i dziedzictwo pedagogiczne, Instytut Badań Pedagogicznych, Zakład Systemów Wychowawczych, Pracownia Korczakowska, Warszawa.

Wołoszyn S. (1978b), Korczak, Wiedza Powszechna, Warszawa.

Wróblewska T. (2003), Aktualność idei Janusza Korczaka, [in:] I.J. Pyrzyk (ed.), Korczak-człowiek, badacz, pedagog $i$ wychowawca, Oficyna Wydawnicza LEGA, Włocławek, pp. 43-53.

Znaniecki F. (2001a), Ludzie teraźniejsi a cywilizacja przyszłości, Wydawnictwo Naukowe PWN, Warszawa.

Znaniecki F. (2001b), Socjologia wychowania, vol. 1, Wychowujace społeczeństwo, Wydawnictwo Naukowe PWN, Warszawa. 


\title{
Marcin Choczyński
}

\section{AKCENTOWANIE ROLI SPOLECZEŃSTWA WYCHOWUJĄCEGO W PEDAGOGICE KORCZAKOWSKIEJ}

\begin{abstract}
Abstrakt. Celem artykułu jest ukazanie socjologicznych elementów w procesie wychowania, które obecne są w pedagogice Korczakowskiej, zarówno w jej naukowej postaci, jak również w twórczości beletrystycznej skierowanej bezpośrednio do dzieci. Zarówno społeczeństwo, jak i jego instytucje wychowawcze (rodzina, szkoła, internat) będą więc odnotowane w tej pedagogice jako ważna płaszczyzna odniesień symbolicznych, wpływów wychowawczych. Kluczowa rola społeczeństwa (jako najważniejszej instytucji wychowawczej) w kształtowaniu wychowanków obecna jest w powszechnie znanych pracach dotyczących socjologii wychowania (m.in. u Floriana Znanieckiego czy też Józefa Chałasińskiego), natomiast wątki socjologiczne w pedagogice Korczakowskiej nie były dotychczas popularnym tematem oddzielnych analiz, oprócz jednej przedmiotowej monografii. Dlatego też temat ten domaga się pogłębionych analiz i uzupełnień. Janusz Korczak uwypukla rolę społeczeństwa w życiu dziecka, przygotowując je przede wszystkim do uczestnictwa w relacjach społecznych poprzez zróżnicowane formy życia grupowego w szkole, której najbardziej doniosłym osiągnięciem jest instytucja samorządu uczniowskiego. Stanowi tym samym pomost pomiędzy wychowaniem zorientowanym na ucznia a tradycyjnym przekazem pedagogicznym, zakładającym przekaz wymagań określonych ról społecznych.
\end{abstract}

Słowa kluczowe: pedagogika Korczakowska, społeczeństwo wychowujące, społeczeństwo dorosłych, społeczeństwo dzieci, dusza kierująca, samorząd uczniowski, plebiscyt życzliwości. 